Vol. 4 No.2 Juni 2021

http://jurnal.umsb.ac.id/index.php/RANGTEKNIKJOURNAL

\title{
Evaluasi Pengembangan Sarana Air Minum Pada Program Pamsimas Kecamatan Kalinyamatan Kabupaten Jepara
}

\author{
Agus B Siswanto ${ }^{1}$, M. Afif Salim ${ }^{2}$, Ristiyanto A Karim ${ }^{3}$ \\ Dosen Prodi Teknik Sipil Fakultas Teknik Universitas 17 Agustus 1945 Semarang ${ }^{1,2}$, Mahasiswa \\ Prodi Teknik Sipil Fakultas Teknik Universitas 17 Agustus 1945 Semarang $^{3}$ \\ email: agus_bambang_iswanto@untagsmg.ac.id ${ }^{1}$ \\ DOI: http://dx.doi.org/10.31869/rtj.v4i2.2616
}

\begin{abstract}
Program penyedian air minum dan sanitasi (PAMSIMAS) merupakan salah satu program pembangun infrastruktur pemerintah dalam memenuhi kebutuhan akses sarana air minum dan sanitasi masyarakat. Tujuan dari penelitian ini adalah Untuk mengetahui dan mengevaluasi pelaksanaan program PAMSIMAS di Kecamatan Kalinyamatan Kabupaten Jepara, Untuk mengetahui kendalakendala apa saja pada pelaksanaan program PAMSIMAS. Dari kendala-kendala tersebut dapat diketahui faktor-faktor untuk mengembangkan sarana air minum, Untuk mengetahui strategi pengembangan PAMSIMAS di Kecamatan Kalinyamatan pada tahun berikutnya.

Fokus penelitian ini adalah untuk mengevaluasi pengembangan program PAMSIMAS yang mengacu pada beberapa variabel yaitu pelaksanaan program (X1), fungsi program (X2) dan rencana kedepan program (Y) di Kecamatan Kalinyamatan Kabupaten Jepara. Metode penelitian ini dilakukan dengan survey dilapangan dan menyebar angket/kuesioner. Dari hasil penelitian didapatkan bahwa hubungan antara variabel $\mathrm{X} 1$ dan $\mathrm{X} 2$ terhadap variabel pengikat yaitu variabel $\mathrm{Y}$ dimana perolehan skor ketiga variabel teresbut sangat berpengaruh besar terhadap pengembangan akses sarana air minum di Kecamatan Kalinyamat Kabupaten Jepara. Variabel pelaksanaan program dengan variabel fungsi program PAMSIMAS memiliki prosentase sebesar 23\% untuk pengembangan Sarana Air Minum (SAM), sisanya 67\% dipengaruhi atau dijelaskan oleh variabel lain yang tidak dimasukan dalam model penelitian ini. Dari hasil uji regresi linier berganda diperoleh persamaan yaitu $\mathbf{Y}=$ 25,699 + 0,182 x X1 + 0,165 x X2. Strategi untuk mengembangkan PAMSIMAS di Kecamatan Kalinyamatan dalam variabel rencana kedepan adalah perlunya meningkatkan fungsi program PAMSIMAS karena masih memiliki nilai positif hanya sebesar 0,165 atau $16,5 \%$. Jika dibandingkan dengan variabel pelaksanaan program PAMSIMAS memiliki nilai positif sebesar 0,182 atau 18,2\%
\end{abstract}

Keywords: Pamsimas, Sarana Air Minum, Kendala, Pengembangan, Kalinyamatan, Jepara

\section{PENDAHULUAN}

Perilaku hidup bersih dan sehat merupakan suatu hal yang sangat penting dan menjadi tantangan tersendiri dalam mewujudkan kesehatan masyarakat. Hal ini disebabkan karena disamping kesadaran masyarakat akan hidup sehat masih diragukan, sarana untuk berperilaku hidup bersih dan sehat di masyarakat pun dirasa masih sangat terbatas. Era Otonomi Daerah saat ini menuntut pemerintah daerah memberikan peningkatan pelayanan kepada masyarakat di semua sektor pembangunan. Salah satu bentuk pelayanan dasar yang menjadi tugas dan tanggungjawab pemerintah daerah kabupaten/kota adalah penyediaan kebutuhan air minum dan sanitasi yang sangat berkaitan erat dengan kondisi kesehatan masyarakat.

Pemerintah Indonesia memiliki komitmen untuk melanjutkan keberhasilan capaian target Millennium Development Goals sektor Air Minum dan Sanitasi (WSS-MDG), yang telah berhasil menurunkan separuh dari proporsi penduduk yang belum mempunyai akses air minum dan sanitasi dasar pada Tahun 2015. Sejalan dengan itu, sesuai dengan Rencana Pembangunan Jangka Menengah Nasional (RPJMN) 2015-2019, Pemerintah Indonesia telah mengambil inisiatif untuk melanjutkan komitmennya dengan meluncurkan program nasional Akses Universal Air Minum dan Sanitasi Tahun 2019 dengan capaian target $100 \%$ akses air minum dan sanitasi bagi seluruh penduduk Indonesia. Program Penyediaan Air Minum dan Sanitasi Berbasis Masyarakat (PAMSIMAS) telah menjadi salah satu program andalan nasional (Pemerintah Pusat dan Pemerintah Daerah) untuk meningkatkan akses penduduk perdesaan terhadap fasilitas air minum dan sanitasi yang layak dengan pendekatan berbasis masyarakat. 
Kabupaten Jepara Memiliki 16 Kecamatan, 184 Desa, 11 Kelurahan. Pada tahun 2014, Program PAMSIMAS ini sudah terealisasikan di beberapa desa meliputi Bucu, Dudakawu, Pendem dan Sumanding Kecamatan Kembang, Srikandang Kecamatan Bangsri. Pada tahun 2015 meliputi desa Damarwulan Kecamatan Keling. tahun 2017 meliputi desa Kepuk Kecamatan Bangsri, Klepu dan Tunahan Kecamatan Keling. tahun 2018 meliputi desa Bumiharjo dan Gelang Kecamatan Keling, desa Karimunjawa Kecamatan Karimunjawa, desa Mororejo dan Srobyong Kecamatan Mlonggo. Dan yang terakhir pada tahun 2019 meliputi desa Banjaragung dan Banjaran Kecamatan Bangsri, desa Dongos Kecamatan Kedung, desa Lebak Kecamatan Pakis Aji, desa Rengging Kecamatan Pecangaan. Sedangkan desa yang mendapatkan program PAMSIMAS III di tahun 2020 ini meliputi desa Geneng dan Ngasem Kecamatan Batealit, dan Desa Pendosawalan Kecamatan Kalinyamatan.

PAMSIMAS di tahun 2021 yang akan datang, ada beberapa usulan desa yang akses Sarana Air Minumnya masih belum sesuai agenda nasional yakni $100 \%$ baik. Oleh karena itu pelayanan air bersih dan sanitasi ini dilakukan melalui dua pendekatan yaitu Pendekatan Berbasis Lembaga melalui Dinas, Badan Perusahaan Daerah, Perusahaan Swasta, dan Pendekatan Berbasis Masyarakat. Adapun aturan Pemerintah Kabupaten untuk desa yang ingin mendapatkan program PAMSIMAS III atau kelanjutan dari PAMSIMAS II ini yaitu, Kecamatan yang sebelumnya sudah pernah mendapat bantuan program PAMSIMAS II dan sebagai berikut kriteria-kriterianya :

1. Adanya Kontribusi dari masyarakat

2. Kesanggupan masyarakat untuk membiayai operasional dan pemeliharaan

3. Indeks kemiskinan yang tinggi di kelurahan

4. Kelurahan yang terbatas terhadap akses air minum (air bersih) dan sanitasi.

5. Kelurahan dengan preverensi penyakit terkait air (diare) tinggi.

Sebagai Perusahaan Daerah Air Minum (PDAM) yang memberikan jasa pelayanan untuk mencukupi kebutuhan air bersih yang layak konsumsi belum mampu memenuhi seluruh kebutuhan masyarakat, bahkan masyarakat cenderung lebih memilih mengeluarkan uang ekstra untuk membeli AMDK (Air Minum Dalam Kemasan). Itulah kekurangan dari PDAM yang kemudian menjadi masalah bagi masyarakat miskin, dimana mereka sulit memenuhi kebutuhan air minum yang berkualitas karena dipengaruhi keadaan ekonomi.

Berbeda dengan Program Penyediaan Air Minum dan Sanitasi Berbasis Masyarakat (PAMSIMAS) yaitu untuk mengembangkan akses sarana air minum bersumber langsung dari APBN dan APBD, dimana masyarakat tinggal mengeluarkan uang sebagai pengganti instalasi ke sambungan rumah (SR) untuk mendapatkan kebutuhan air bersih yang sudah layak.

Setelah adanya program PAMSIMAS, pada awalnya masyarakat merasa sangat terbantu karena memperoleh sarana air bersih yang lebih murah, akan tetapi tidak semua masyarakat dari beberapa kelurahan di Kabupaten Jepara yang diberikan bantuan PAMSIMAS terpenuhi kebutuhan air bersihnya. Seperti masalah yang ada di pendampingan desa pasca yaitu Kecamatan Kalinyamatan yang mendapat PAMSIMAS di tahun 2016, 2018 dan tahun 2020 yang sudah terealisasikan di beberapa desa di Kecamatan Kalinyamatan. Dimana sarana yang terbangun masih berfungsi dengan baik namun ada berbagai permasalah yang dihadapi dari berbagai faktor.

Permasalahan-permasalahan dalam program PAMSIMAS diatas di sebabkan oleh beberapa hal baik itu yang berasal dari masyarakat maupun dari lembaga pelaksana/pengelola sebagai berikut :

1. Keterbatasan waktu yakni masa pelaksanaan pembangunan dimana program menuntut masyarakat yang mendapat bantuan bisa secara mandiri mengelola sarana yang disediakan, dan sosialisasi program di setiap kecamatan yang hanya berjalan 1 tahun tidak cukup untuk mengubah perilaku hidup sehat masyarakat, karena hal ini sangat terkait dengan merubah mainset atau kebiasaan dari masyarakat itu sendiri.

2. Prinsip kebutuhan manusia yang tidak terbatas sementara sumber daya untuk memenuhinya adalah terbatas merupakan salah satu latar belakang terjadinya pemasalahan-permasalahan diatas. Tidak bisa dipungkiri populasi yang semakin 
banyak menuntut pelayanan sarana yang semakin besar pula.

3. Kurang koordinasi antara BPS dengan masyarakat dalam menghadapi persoalanpersoalan yang ada, sehingga sulit mencarikan solusi yang tepat dan diterima seluruh masyarakat. Keempat, sebelum pelaksanaan program pihak pelaksana kurang melakukan pengamatan mengenai topografi daerah yang diberikan bantuan, sehingga konsep pembagian air secara adil tidak dirasakan sama oleh seluruh masyarakat.

Melihat latar belakang tersebut, maka penulis akan membahas evaluasi pengembangan sarana air minum (SAM) melalui program PAMSIMAS studi kasus di Kecamatan Kalinyamatan Kabupaten Jepara.

1. Bagaimana evaluasi pelaksanaan program PAMSIMAS di Kecamatan Kalinyamatan Kabupaten Jepara?

2. Apa kendala pelaksanaan program PAMSIMAS di Kecamatan

Kalinyamatan Kabupaten Jepara?

3. Bagaimana strategi pengembangan PAMSIMAS untuk tahun berikutnya di Kecamatan Kalinyamatan Kabupaten Jepara?

Sejak tahun 2014 program PAMSIMAS di Kabupaten Jepara mengalami perkembangan, namun juga terdapat kendala dalam pemenuhan kebutuhan air minum di saat musim kemarau. Oleh sebab itu, perlu dilakukan evaluasi pengelolaan program PAMSIMAS untuk keberlanjutan program di masa yang akan datang. (Program Penyediaan Sarana Air Minum Dan Sanitasi Berbasis Masyarakat (Pamsimas) Fieldbook Proses Identifikasi Masalah Dan Analisis Situasi, 2010)

Dari tahun ke tahun jumlah sarana air minum (SAM) yang dibangun melalui program PAMSIMAS terus bertambah dan pengelolaannya diserahkan kepada KPSPAMS (Kelompok Pengelola Sistem Penyediaan Air Minum dan Sanitasi). Kondisi KPSPAMS di setiap desa tentunya beragam, ada yang baru tumbuh, mulai berkembang, sudah maju dan bahkan ada yang telah mandiri, namun demikian juga tentunya ada yang tidak aktif.

\section{Kondisi Pemilihan Sistem Penyediaan Air Minum}

Penyediaan Air Minum dan Sanitasi Berbasis Masyarakat (PAMSIMAS) adalah sebuah program andalan pemerintah untuk menunjang akses sarana air minum dan sanitasi umum. PAMSIMAS ini sudah 24 tahun lebih hadir untuk Indonesia dengan 33 propinsi, 396 kabupaten, 11 kota, dan 27.000 desa, PAMSIMAS ada disana. Saat ini Program PAMSIMAS memasuki fase ketiga (PAMSIMAS III) yang dilaksanakan pada kurun waktu 2016-2020, dan akan menyasar 15.000 desa sasaran baru serta mengelola keberlanjutan program di hampir lebih dari 27.000 desa peserta PAMSIMAS di seluruh Indonesia.

Dimana PAMSIMAS I pada tahun 2008-2013 dengan lokasi 15 Provinsi dan PAMSIMAS II yang mendukung pencapaian target MDS sektor air minum dan sanitasi, adapun tujuan PAMSIMAS I yaitu meningkatkan jumlah warga miskin perdesaan dan pinggiran kota (peri-urban) yang dapat mengakses air minum dan sanitasi yang layak serta mempraktekkan prilaku hidup bersih dan sehat. Dan PAMSIMAS II.

Sistem Penyediaan Air Minum (SPAM) perkotaan di Kabupaten Jepara dilayani oleh PDAM yang saat ini bernama Perumda Air Minum Tirta Jungporo.

Perumda Air Minum adalah BUMD (Badan Usaha Milik Daerah) yang bertugas memiliki tingkat pelayanan yang bertahap dan target yang harus dicapai

Tabel 1. Data Produksi Wilayah PDAM

\begin{tabular}{|l|c|c|c|c|}
\hline No & Wilayah & Lokasi & $\begin{array}{c}\text { Kapasitas } \\
\text { Terpasang (Lt/dt) }\end{array}$ & $\begin{array}{c}\text { Kapasitas Produksi } \\
(\mathbf{L t} / \mathbf{d t})\end{array}$ \\
\hline 1 & Jepara Pusat & Pekalongan & 3,00 & 2,40 \\
\hline & & Karanganyar & 2,00 & 1,50 \\
\hline & & Kecapi & 3,00 & 2,00 \\
\hline & & Bulungan & 9,50 & 7,30 \\
\hline & & Suwawal & - & - \\
\hline & & Kecapi & 3,00 & 3,00 \\
\hline
\end{tabular}




\begin{tabular}{|c|l|c|c|c|}
\hline & & Kuwasen & 9,00 & 6,50 \\
\hline & & Wonorejo & 3,00 & 2,80 \\
\hline & & Senenan & 10,5 & 10,50 \\
\hline & & Pengkol & 2,00 & 1,70 \\
\hline & & Bapangan & 12,50 & 12,00 \\
\hline & & Ngasem & 11,50 & 11,40 \\
\hline No & Wilayah & Lokasi & $\begin{array}{c}\text { Kapasitas } \\
\text { Terpasang (Lt/dt) }\end{array}$ & $\begin{array}{c}\text { Kapasitas Produksi } \\
\text { (Lt/dt) }\end{array}$ \\
\hline & & Krapyak & 14,50 & 14,50 \\
\hline 2 & Cab.Bangsri & Bangsri & 18,70 & 15,90 \\
\hline 3 & Cab.Mlonggo & Sinanggul & 21,00 & 19,00 \\
\hline & & Jambu & 11,00 & 10,70 \\
\hline 4 & Cab.Pecangaan & Lebuawu & 3,00 & 2,10 \\
\hline & & Rengging & 3,00 & 2,90 \\
\hline & & Pulodarat & 4,00 & 3,70 \\
\hline 5 & Cab.Tahunan & Tahunan & 33,00 & 22,10 \\
\hline 6 & Cab.Kalinyamatan & Margoyoso & 13,505 & 13,00 \\
\hline & & Sendang & 9,50 & 9,00 \\
\hline 7 & Cab.Kedung I & Purwogondo & 10,00 & 8,00 \\
\hline & & Wanusobo & 6,00 & 5,20 \\
\hline 8 & Cab.Kedung II & Sowan & 8,00 & 6,00 \\
\hline & & Dongos & 8,00 & 5,00 \\
\hline 9 & Cab.Mayong & Mayong & - & - \\
\hline
\end{tabular}

Sumber : Jakstrada SPAM Kab. Jepara Tahun 2020 - 2024

Begitu juga dengan PAMSIMAS

III ini yang memiliki capaian dan target yaitu memfasilitasi $100-100$ akses air dimaksudkan $100 \%$ akses air minum yang baik dan $100 \%$ akeses sanitasi yang layak. minum dan sanitasi. 100-100 disini

Tabel 2. Data Wilayah Sarana Air Minum (SAM) di Kecamatan Kalinyamatan Kabupaten Jepara

\begin{tabular}{|c|c|c|c|c|c|c|c|}
\hline \multirow[t]{2}{*}{ Kecamatan } & \multirow[t]{2}{*}{ Tahun } & \multirow[t]{2}{*}{ Lokasi } & \multicolumn{2}{|c|}{$\begin{array}{c}\text { Jumlah } \\
\text { Penduduk }\end{array}$} & \multicolumn{2}{|c|}{$\begin{array}{c}\text { Penerima } \\
\text { Manfaat }\end{array}$} & \multirow{2}{*}{$\begin{array}{c}\text { Sumber } \\
\text { Air }\end{array}$} \\
\hline & & & KK & Jiwa & SR & Jiwa & \\
\hline \multirow{7}{*}{ Kalinyamatan } & 2016 & Desa Damarjati & 1.277 & 5.109 & 325 & 1.300 & \multirow{7}{*}{$\begin{array}{l}\text { Sumur } \\
\text { Bor } \\
\text { Dalam }\end{array}$} \\
\hline & 2018 & $\begin{array}{c}\text { Desa } \\
\text { Banyuputih }\end{array}$ & 1.300 & 5.200 & 173 & 692 & \\
\hline & \multirow{3}{*}{2020} & $\begin{array}{c}\text { Desa } \\
\text { Pendosawalan }\end{array}$ & 1.331 & 5.322 & 250 & 1.000 & \\
\hline & & $\begin{array}{c}\text { Desa } \\
\text { Banyuputih }\end{array}$ & 1.463 & 5.853 & 198 & 792 & \\
\hline & & Desa Damarjati & 1.841 & 7.363 & 337 & 1.348 & \\
\hline & \multirow[t]{2}{*}{2021} & $\begin{array}{c}\text { Desa } \\
\text { Banyuputih }\end{array}$ & 1.506 & 6.024 & 250 & 1.000 & \\
\hline & & Desa Damarjati & 1.878 & 7.511 & 359 & 1.435 & \\
\hline
\end{tabular}

Sumber : Kegiatan Air Minum yang ditangaini Disperkim 2020

\section{Pedoman Program PAMSIMAS}

Petunjuk Pelaksanaan ini memberikan arahan kepada Pemerintah Desa dan pihak lainnya yang terkait dalam pelaksanaan kerjasama desa untuk kegiatan air minum dan sanitasi dengan ruang lingkup yang meliputi :
1) Kerja-sama Desa sebagai strategi keberlanjutan Penyediaan Air Minum dan sanitasi di desa

2) Jenis Kerja-sama Desa untuk kegiatan air minum dan sanitasi.

3) Tata Cara Kerja-sama Desa untuk kegiatan air minum dan sanitasi 
4) Pembinaan dan Pengawasan Kerja-sama Desa untuk kegiatan air minum dan sanitasi.

Petunjuk Pelaksanaan ini juga dilengkapi dengan lampiran yang berisi contoh maupun format yang dapat mempermudah Pemerintah Desa dan para pihak dalam

Tabel 2. Penggunaan dan Manfaat Petunjuk Pelaksanaan

\begin{tabular}{|c|c|}
\hline Pengguna & Manfaat \\
\hline $\begin{array}{l}\text { Pemerintah (Pusat, Provinsi, Kabupaten, } \\
\text { Kecamatan dan Desa) }\end{array}$ & $\begin{array}{l}\text { - Menjadi dasar dalam menetapkan kebijakan } \\
\text { pemerintah terkait kerjasama desa untuk kegiatan } \\
\text { air minum. } \\
\text { - Menjadi dasar untuk melakukan pembinaan dan } \\
\text { pengawasan dalam pelaksanaan kegiatan. }\end{array}$ \\
\hline $\begin{array}{l}\text { Pengelola Program (CPMU, PPMU dan } \\
\text { DPMU, Pokja AMPL Provinsi dan } \\
\text { Kabupaten) }\end{array}$ & $\begin{array}{l}\text { - Menjadi pedoman pengendalian untuk pencapaian } \\
\text { target. }\end{array}$ \\
\hline $\begin{array}{l}\text { Konsultan Pelaksana (NCM, ROMS dan } \\
\text { DC) }\end{array}$ & $\begin{array}{l}\text { - Memfasilitasi pengelola program di pusat dan } \\
\text { daerah dalam pelaksanaan kegiatan. } \\
\text { - } \quad \text { Mengkoordinir dan mengembangkan kapasitas }\end{array}$ \\
\hline $\begin{array}{l}\text { Fasilitator Senior, Fasilitator Masyarakat, } \\
\text { Kader AMPL, Pendamping desa serta } \\
\text { Sanitarian dan Kader kesehatan }\end{array}$ & $\begin{array}{l}\text { - Memfasilitasi pemerintahan desa dan masyarakat } \\
\text { dalam pengendalian mutu pekerjaan. }\end{array}$ \\
\hline $\begin{array}{l}\text { Badan Permusyawaratan Desa, Lembaga } \\
\text { Adat Desa, BUM Desa, Lembaga } \\
\text { Kemusyarakatan Desa, KKM dan KP- } \\
\text { SPAM }\end{array}$ & $\begin{array}{l}\text { - Memahami tata cara kerjasama desa untuk } \\
\text { kegiatan air minum. } \\
\text { - } \quad \text { Pedoman dalam melaksanakan kerjasama desa } \\
\text { untuk kegiatan air minum. }\end{array}$ \\
\hline
\end{tabular}

Sumber : SNI- 01-0220-1987 Tentang Pengguna dan Manfaat Petunjuk Pelaksanaan Air Minum

\section{Kegiatan Sarana Air Minum (SAM) pada Program PAMSIMAS}

Untuk mendukung kapasitas Pemerintah Daerah dalam menyediakan layanan air minum dan sanitasi yang memenuhi Standar Pelayanan Minimal (SPM), Program Pamsimas berperan dalam menyediakan dukungan finansial baik untuk investasi fisik dalam bentuk mengadministrasikan kerjasama desa untuk kegiatan air minum dan sanitasi.

Pengguna Petunjuk Pelaksanaan ini adalah seluruh pemangku kepentingan yang berperan dalam mewujudkan akses universal air minum dan sanitasi. (Pemerintah Direktorat Jendral Bina \& Indonesia, 2008)

Tabel 3. Kegiatan Sarana Air Minum (SAM) di Kecamatan Kalinyamatan

\begin{tabular}{|c|c|c|c|c|c|c|c|}
\hline \multirow[t]{2}{*}{ Kecamatan } & \multirow[t]{2}{*}{ Tahun } & \multirow[t]{2}{*}{ Lokasi } & \multicolumn{2}{|c|}{$\begin{array}{c}\text { Jumlah } \\
\text { Penduduk }\end{array}$} & \multicolumn{2}{|c|}{$\begin{array}{c}\text { Penerima } \\
\text { Manfaat }\end{array}$} & \multirow{2}{*}{$\begin{array}{c}\text { Sumber } \\
\text { Air }\end{array}$} \\
\hline & & & KK & Jiwa & SR & Jiwa & \\
\hline \multirow{7}{*}{ Kalinyamatan } & 2016 & Desa Damarjati & 1.277 & 5.109 & 325 & 1.300 & \multirow{7}{*}{$\begin{array}{l}\text { Sumur } \\
\text { Bor } \\
\text { Dalam }\end{array}$} \\
\hline & 2018 & Desa Banyuputih & 1.300 & 5.200 & 173 & 692 & \\
\hline & \multirow{3}{*}{2020} & Desa Pendosawalan & 1.331 & 5.322 & 250 & 1.000 & \\
\hline & & Desa Banyuputih & 1.463 & 5.853 & 198 & 792 & \\
\hline & & Desa Damarjati & 1.841 & 7.363 & 337 & 1.348 & \\
\hline & \multirow{2}{*}{2021} & Desa Banyuputih & 1.506 & 6.024 & 250 & 1.000 & \\
\hline & & Desa Damarjati & 1.878 & 7.511 & 359 & 1.435 & \\
\hline
\end{tabular}

Sumber : Kegiatan Air Minum yang ditangani Disperkim 2020 sarana dan prasarana, maupun investasi non-fisik dalam bentuk manajemen, dukungan teknis, dan pengembangan kapasitas. Kabupaten Jepara mengikuti Program PAMSIMAS mulai Tahun 2014 atau pada PAMSIMAS II. Lebih jelasnya dapat dilihat pada tabel berikut.

Air Merupakan kebutuhan mendasar bagi semua makhluk hidup dalam kehidupan sehari-hari. Tidak semua orang bisa mengakses air bersih dan mendapatkan 
sanitasi yang memadai untuk kebutuhan hidup. Untuk mempercepat pelayanan air minum perlu digalakan pembangunan partisipatif yang melibatkan masyarakat sebagai subyek dalam penyelenggaraan air minum. Pemerintah secara bertahap akan berubah dari penyedia prasarana menjadi peran pemberdaya dan fasilitator.

Dalam PP No.16 Tahun 2005 tentang Pengembangan Sistem Penyediaan Air Minum menyebutkan bahwa peran serta masyarakat dalam penyelenggaraan sistem penyediaan air minum perlu di dorong dala rangka perubahan perilaku masyarakat menuju budaya hidup yang lebih sehat serta mendukung keberlanjutan pelayanan air minum dan sanitasi yang lebih handal. (Balitbang PU, 2013). Air Minum adalah air yang memenuhi persyaratan air minum sesuai dengan SNI 010220-1987

\section{Kegiatan Program PAMISMAS}

Berdasarkan Pedoman Umum

Program PAMSIMAS disebutkan bahwa pembiayaan PAMSIMAS berasal dari berbagai sumber pendanaan yaitu dana pemerintah (APBN dan APBD Provinsi dan APBD Kabupaten), dana masyarakat (swadaya masyarakat), dan swasta/ donor/ Lembaga Swadaya Masyarakat (LSM), serta sumber dana lain yang tidak mengikat. Kontribusi yang utama bersumber dari stakeholder Kabupaten berupa alokasi dana dan sumber daya manusia dan dari masyarakat berupa kontribusi uang $4 \%$ dan tenaga $16 \%$ sangat dibutuhkan dalam pelaksanaan program PAMSIMAS.

Kriteria desa sasaran PAMSIMAS menurut Pedoman Umum Program PAMSIMAS diantaranya :

1. Belum mendapatkan program PAMSIMAS

2. Memiliki potensi sumber air yang dapat digunakan, baik wilayah desa kelurahan sasaran atau desa sekitarnya

3. Adanya pernyataan kesanggupan masyarakat untuk memenuhi persyaratan mengikuti program (Kader AMPL, Kontribusi, Stop BABS, menjamin penetapan iuran, dan melaksanakan petunjuk teknis)

Pedoman ini memberikan pedoman tata cara pemilihan jenis, perencanaan, pelaksanaan fisik dan pengoperasian serta pemeliharaan prasarana dan sarana penyediaan air minum berbasis Masyarakat. Ruang lingkup Program Pamsimas mencakup lima komponen program :
1. Pemberdayaan masyarakat pengembangan kelembagaan daerah dan desa
2. Peningkatan perilaku higienis dan pelayanan sanitasi
3. Penyediaan sarana air minum dan sanitasi umum
4. Hibah Insentif dan,
5. Dukungan teknis dan manajemen pelaksanaan program.

Dengan adanya ruang lingkup tersebut, penulis akan mengevaluasi dalam satu komponen ruang lingkup yaitu pada Penyediaan Sarana Air Minum dan Sanitasi Umum.

\section{Pedoman Teknis Pelaksanaan PAMSIMAS}

Penyediaan Air Minum dan Sanitasi Berbasis Masyarakat (PAMSIMAS) memiliki suatu pedoman teknis pelaksanaan yang biasanya dibuat oleh Kelompok Keswadayaan Masyarakat (KKM) yang disusun dalam dokumen Rencana Kerja Masyarakat (RKM).

\section{A. Pengertian Kelompok Keswadayaan Masyarakat}

Kelompok Keswadayaan Masyarakat (KKM) adalah wadah sinergi dan aspirasi masyarakat yang diharapkan menjadi embrio dari lembaga keswadayaan masyarakat (civil society) ditingkat komunitas. KKM ini memiliki struktur organisasi dan Kelompok Pengelola Sistem Penyediaan Air Minum (KPSPAM).

Di desa Pendosawalan sendiri dikelola oleh pihak KKM "Manunggal Jaya". KKM diharapkan menjadi lembaga masyarakat yang independent, yang sepenuhnya dibentuk, dikelola dan dipertanggungjawabkan oleh masyarakat sendiri. Anggota KKM dipilih secara langsung oleh masyarakat dengan 
mengutamakan keterlibatan dan keberpihakan kepada kelompok yang selama ini terpinggirkan (wanita dan Masyarakat miskin), mengacu pada kriteria kualitas sifat kemanusiaan (moral) dan berbasis nilai.

Pemilihan anggota KKM melalui sistem tanpa calon, tanpa kampanye, tertulis, rahasia, tanpa rekayasa dari pihak manapun dan disepakati oleh seluruh warga.

Untuk kemudahan administrasi program dan sejalan dengan kedudukannya sebagai lembaga masyarakat warga yang otonom, maka pengesahan KKM adalah pengakuan, representasi dan mengakarnya lembaga tersebut dalam masyarakat, sedangkan legalisasinya melalui pencatatan di Notaris.

KKM merupakan lembaga masyarakat yang mempunyai kedudukan otonom, namun dalam pengelolaan organisasinya maupun pelaksanaan kegiatan, KKM berkewajiban melaksanakan koordinasi, konsultasi dan komunikasi intensif dengan petinggi dan perangkatnya (Pemerintah Desa) serta tokoh masyarakat maupun lembaga formal dan lembaga informal masyarakat.

Proses pembentukan KKM sesuai dengan asas Representasi, Partisipasi, Akuntabel, berbasis nilai dan dilaksanakan sepenuhnya oleh masyarakat dengan kriteria anggota yang lebih mengutamakan rekam jejak (track record) atau kepercayaan masyarakat dan menjamin keterlibatan perempuan serta warga miskin.

\section{Ketentuan Kelompok Keswadayaan Masyarakat (KKM)}

1. Kelompok Keswadayaan Masyarakat ( KKM ) bukan lembaga yang dibentuk secara otomatis mengikuti perundangundangan atau peraturan pemerintah (pusat maupun daerah) yang dibuat sebagai alat kelengkapan lembaga pemerintah, tetapi merupakan lembaga yang pembentukan dan pengelolaannya diprakarsai dan ditentukan oleh masyarakat. Kekuasaan/kewenangan dan pengesahan bersumber dari warga masyarakat setempat.

2. Kelompok Keswadayaan Masyarakat (KKM) berkedudukan sebagai lembaga kepimpinan kolektif dan oleh karenanya juga berperan sebagai representasi warga yang berhimpun dalam suatu himpunan masyarakat warga setempat yang bersifat organisasi anggota atau bertumpu pada anggota, artinya keputusan tertinggi ada di tangan anggota.

3. Kelompok Keswadayaan Masyarakat (KKM) tidak harus dibentuk jika di masyarakat telah ada lembaga yang memiliki kriteria dan fungsi KKM.

4. Kelompok Keswadayaan Masyarakat (KKM) dibentuk secara partisipatif, demokratis, dan inklusif. KKM bekerja secara kolektif, transparan, partisipatif, demokratis dan akuntabel.

5. Kelompok Keswadayaan Masyarakat (KKM) harus mampu mempertahankan sifat independen dan otonom terhadap institusi pemerintah, politik, militer, agama, usaha dan keluarga.

6. Kelompok Keswadayaan Masyarakat (KKM) adalah lembaga eksekutif dengan peran utama sebagai pengendali (steering) bukan sebagai pelaksana (implementing), oleh sebab itu KKM dapat membentuk Unit Pelaksana (UP) dan Satuan Pelaksana (Satlak). Namun anggota KKM tidak boleh dipilih/merangkap menjadi anggota Satlak.

7. Keanggotaan Kelompok Keswadayaan Masyarakat (KKM) :

a) Pemilihan anggota KKM dilakukan melalui proses pemilihan secara langsung oleh warga masyarakat, tertulis, rahasia, tanpa pencalonan, dan tanpa kampanye maupun rekayasa dari siapapun.

b) Semua warga dewasa di desa pada dasarnya dapat dipilih sebagai anggota KKM bila memenuhi kriteria yang telah disepakati warga. Namun demikian untuk perangkat desa yang masih aktif bekerja tidak dapat dipilih menjadi anggota KKM.

c) Jumlah anggota KKM antara $5 \mathrm{~s} / \mathrm{d} 9$ orang dan harus ganjil.

\section{Evaluasi Pengembangan Sarana Air Minum (SAM)}

Pengertian evaluasi yang dikemukakan oleh para ahli seperti yang dikemukakan oleh Scriven yang dikutip oleh Fitzpatrick, Sanders dan Worthen menyatakan bahwa "evaluation as judging the worth or merit of something". 
Menurut Sudjiono (2007), evaluasi adalah sebuah interpretasi atau penafsiran yang bersumber pada data-data kuantitatif, menurut pengertiannya sendiri kuantitatif merupakan hasil-hasil dari pengukuran.

Dalam penelitian ini, penulis menggunakan tipe penelitian deskriptif dengan pendekatan kualitatif. Penelitian ini beralokasi di desa Damarjati , desa Banyuputih dan desa Pendosawalan di Kecamatan Kalinyamatan Kabupaten Jepara. Informan (pihak terkait yang mempunyai banyak sumber) pada penelitian ini adalah seluruh elemen yang berwenang menangani PAMSIMAS di Kecamatan Kalinyamatan. Data yang sudah diperoleh dari hasil kuesioner dengan pihak terkait dikumpulkan kemudian di evaluasi data melalui reduksi dengan mengelompokan halhal pokok, kemudian disajikan dan pada akhirnya dilakukan penarikan kesimpulan atas jawaban-jawaban informan.Menurut data-data dari Dinas Perumahan Umum dan Kawasan Permukiman tahun 2020, Desa Damarjati Kecamatan Kalinyamatan pada tahun 2016, memiliki jumlah penduduk 5.109 jiwa namun penerima manfaatnya hanya 1.300 jiwa. Desa Banyuputih Kecamatan Kalinyamatan pada tahun 2018, memiliki jumlah penduduk 5.200 jiwa namun penerima manfaatnya hanya 692 jiwa. Desa Pendosawalan Kecamatan Kalinyamatan pada tahun 2018, memiliki jumlah penduduk 5.200 jiwa namun penerima manfaatnya hanya 692 jiwa.

Tabel 5. Data Kegiatan Air Minum Di Kecamatan Kalinyamatan

\begin{tabular}{|c|c|c|c|c|c|c|c|}
\hline \multirow[t]{2}{*}{ Kecamatan } & \multirow[t]{2}{*}{ Tahun } & \multirow[t]{2}{*}{ Lokasi } & \multicolumn{2}{|c|}{$\begin{array}{c}\text { Jumlah } \\
\text { Penduduk }\end{array}$} & \multicolumn{2}{|c|}{$\begin{array}{c}\text { Penerima } \\
\text { Manfaat }\end{array}$} & \multirow{2}{*}{$\begin{array}{c}\text { Sumber } \\
\text { Air }\end{array}$} \\
\hline & & & KK & Jiwa & SR & Jiwa & \\
\hline \multirow{7}{*}{ Kalinyamatan } & 2016 & Desa Damarjati & 1.277 & 5.109 & 325 & 1.300 & \multirow{7}{*}{$\begin{array}{l}\text { Sumur } \\
\text { Bor } \\
\text { Dalam }\end{array}$} \\
\hline & 2018 & Desa Banyuputih & 1.300 & 5.200 & 173 & 692 & \\
\hline & \multirow{3}{*}{2020} & $\begin{array}{c}\text { Desa } \\
\text { Pendosawalan } \\
\end{array}$ & 1.331 & 5.322 & 250 & 1.000 & \\
\hline & & Desa Banyuputih & 1.463 & 5.853 & 198 & 792 & \\
\hline & & Desa Damarjati & 1.841 & 7.363 & 337 & 1.348 & \\
\hline & \multirow{2}{*}{2021} & Desa Banyuputih & 1.506 & 6.024 & 250 & 1.000 & \\
\hline & & Desa Damarjati & 1.878 & 7.511 & 359 & 1.435 & \\
\hline
\end{tabular}

Sumber : Hasil Dinas Perumahan Rakyat dan Kawasan Permukiman Kabupaten Jepara (2020)

\section{Faktor-faktor yang Mempengaruhi Pengembangan Sarana Air Minum (SAM)}

Di Kabupaten Jepara sumber air yang digunakan adalah sumur bor dengan menggunakan menara air dan menggunakan pipa transmisi dan distribusi serta pengeboran sumur dengan kedalaman kurang lebih 100 meter sehingga bisa menghasilkan debit air yang cukup banyak untuk memenuhi kebutuhan air minum di Kecamatan Kalinyamatan Kabupaten Jepara, sistem yang akan digunakan oleh 3 desa di Kecamatan Kalinyamatan nantinya akan menggunakan jaringan perpipaan sesuai dengan kebutuhan dilapangan dan telah disepakati oleh warga dan pemerintah desa, serta telah di sinkronkan dengan PJM Proaksi yang telah disusun oleh KKM setempat. Hal yang menjadi faktor pada penelitian ini diantaranya :

1. Keberhasilan program PAMSIMAS
2. Ketepatan waktu pelaksanaan

3. Kontribusi masyarakat terhadap program PAMSIMAS

4. Tujuan akhir program PAMSIMAS

5. Kepuasan

6. Keberfungsian

\section{Indikator-indikator dalam Pengembangan Sarana Air Minum (SAM)}

Berdasarkan penjelasan diatas, maka dalam menentukan pengembangan sarana air minum melalui program PAMSIMAS dipengaruhi oleh beberapa faktor untuk menentukan indikator pengembangan sarana air minum (SAM) diantaranya sebagai berikut:

\section{A. Keberhasilan program PAMSIMAS}

David C.Korten (1984 : 180) berpendapat bahwa daya kerja dari suatu program pembangunan adalah fungsi kesesuaian antara mereka yang dibantu program dan organisasi yang membantu. Dengan istilah yang lebih 
khusus, program pembangunan akan gagal memajukan kesejahteraan suatu kelompok jika tidak ada hubungan yang erat antara kebutuhan-kebutuhan pihak penerima bantuan dengan hasil program, persyaratan program dengan kemampuan nyata dari organisasi pembantu dan kemampuan pengungkapan kebutuhan oleh pihak penerima dan proses pengambilan keputusan dari organisasi pembantu.

Berdasarkan teori diatas, maka dapat ditemukan indikator keberhasilan program PAMSIMAS yaitu :

\section{Pemerintah Desa}

Kebutuhan yang pertama adalah kapasitas dan kemauan dari pemerintah, dalam hal ini tingkat lokal untuk mendukung masyarakat lokal (Briscoe et al,1988). Berhasil tidaknya sebuah program sarana air minum akan terjadi ketika beberapa kondisi kritis dapat terpenuhi salah satunya adalah tugas dan tanggungjawab pemerintah dan masyarakat ditentukan secara jelas dan kewajiban tersebut dapat terpenuhi. Pemerintah dalam hal ini adalah pemerintah pusat sampai pada pemerintah lokal tingkat desa yang melaksanakan program pemberdayaan.

2. Masyarakat

Kondisi masyarakat atau komunitas yang giat dalam melaksanakan program sering menjadi kunci sukses atau keberhasilan dalam pengembangan berbasis masyarakat, apapun bentuk aktivitasnya (Nayaran,1995).

3. Kebutuhan

Pendekatan berdasarkan kebutuhan (demand respon approach) adalah tindakan dari institusi yang bertanggungjawab pada penyediaan air minum terhadap kebutuhan dari suatu komunitas atau organisasi masyarakat. Institusi ini harus berubah dari pemberi kebutuhan menjadi pihak yang memfasilitasi atas keputusan yang dibuat masyarakat(UNICEF,

1999).

Keterbatasan kemampuan pemerintah untuk berhasil dalam mengelola sumber alam, menyediakan infrastruktur dasar dan memastikan pelayanan dasar menimbulkan inisiatif untuk dilakukan penelitian.

\section{B. Ketepatan waktu pelaksanaan PAMSIMAS}

Menurut Goverde (1980), ketepatan waktu mengandung arti bahwa pelaksanaan pelayanan di masyarakat dapat diselesaikan dalam kurun waktu yang telah ditentukan. Ketepatan waktu dapat dilakukan apabila adanya sinergi antara pihak organisasi pengelola dan masyarakat yang menerima manfaat program dalam hal pelaksanaan dapat mencapai sebuah program dengan tepat pelaksanaannya.

Maka dari pernyataan diatas dapat diketahui indikator ketepatan waktu pelaksanaan pada program PAMSIMAS yaitu:

1. Keterlibatan

Partisipasi diberlakukan sebagai alat untuk meningkatkan efisiensi dalam sebuah program dengan asumsi masyarakat terlibat dalam program tersebut dan menjadi bagian dalam operasionalnya. Hal ini terlihat juga sebagai hak dasar yaitu masyarakat sebagai penerima manfaat harus menanggapi atas semua intervensi dari luar yang mempengaruhi kehidupannya (Hayson, 2006).

Penerima manfaat menjadi pemain utama dalam sebuah tahapan, mulai dari persiapan sampai pada operasi dan perawatan sarana air minum (Briscoe, et al, 1988), tugas tersebut termasuk :

- Studi, membuat saran berdasarkan pengalaman komunitas itu sendiri.

- Persiapan proyek, partisipasi dalam survey topografi.

- Promosi, membantu orang-orang yang mampu dalam mengelola masyarakat dalam rangka proyek air minum.

- Kontruksi, menyediakan materialmaterial lokal, pekerja, biaya logistic, menjalankan usaha untuk mengumpulkan dana dari masyarakat itu sendiri.

- Administrasi dan pengawasan, kontribusi secara dana dan keorganisasian untuk kepengurusan pengelola yang akan bertanggungjawab pada operasi, perawatan dan administrasi dari sarana yang telah terbangun.

2. Teknis

Faktor teknis ini berhubungan dengan pemilihan teknologi atau proses pelaksanaan yang sesuai dengan 
kemampuan teknis masyarakat dan dukungan operasional, perawatan yang dibutuhkan sebagai konsekuensi pemilihan teknis tersebut.

\section{Kontribusi masyarakat terhadap program PAMSIMAS}

Kontribusi berasal dari Bahasa inggris yaitu contribute, contribution, maknanya yaitu keikutsertaan, keterlibatan, melibatkan diri maupun sumbangan. Dengan kontribusi berarti individu (masyrakat penerima) juga berusaha meningkatkan efisiensi dan efektivitas dalam hal pelaksanaan.

Dalam hal kontribusi masyarakat terhadap program PAMSIMAS adapun indikatornya yaitu :

1. Peran masyarakat sebagai penerima manfaat

Semakin bertambah tiap tahunnya, tidak mungkin jika penerima manfaatnya tiap tahun semakin menurun. Meningkatkan akses masyarakat, terutama masyarakat miskin pada fasilitas air minum yang layak sebesar $50 \%$ $100 \%$ dari masyarakat 3 desa di Kecamatan Kalinyamat yang belum memiliki akses.

2. Peran masyarakat sebagai pelaksana program

Dari pendataan, pencapaian yang sesuai dengan pedoman pelaksanaan dari pengelola.

3. Partisipasi seluruh anggota yang terlibat dalam program PAMSIMAS

KKM, KSM dan KP-SPAM di desa Damarjati, Banyuputih dan Pendosawalan Kecamatan Kalinyamatan yang ikut berperan dalam hal memahami pedoman tata cara kerjasama desa untuk di sampaikan ke masyarakat, dan melaksanakan kerjasama desa sesuai dengan pedoman program PAMSIMAS untuk hal pelayanan pihak pengelola program ke masyarakat untuk kegiatan sarana air minum.

4. Perawatan dari infrastruktur yang terbangun

Perawatan infrastruktur yaitu kondisi fisik infrastruktur, prosedur perawatan dan penerima manfaat di Kecamatan Kalinyamatan terlibat dalam hal ini.

\section{Tujuan akhir program PAMSIMAS}

Dalam tujuan akhir program PAMSIMAS sendiri bertujuan untuk meningkatkan praktik hidup bersih dan sehat di masyarakat, meningkatkan jumlah masyarakat yang memiliki akses air minum dan sanitasi yang berkelanjutan, meningkatkan kapasitas masyarakat dan kelembagaan (pemerintah daerah maupun masyarakat desa) dalam penyelenggaraan pelayanan.

1. Keberlanjutan

Untuk keberlanjutan program PAMSIMAS pengembangan sarana air minum dapat dipertimbangkan dari aspek berikut :

- Lingkungan

Salah satu faktor keberlanjutan adalah lingkungan yang merujuk pada sumber air. Pengguna yang melebihi kapasitas sumber dan kontaminasi sumber air dari irigasi, industrialisasi dan limbah pembuangan mengancam persediaan air minum yang layak dan aman.

- Ekonomis

Keberlanjutan secara ekonomis merujuk pada keberlanjutan keuangan. Sistem hanya dapat berjalan jika sumber daya keuangan memenuhi setidaknya biaya operasi, pemeliharaan dan pemulihan. Unsur kesejajaran berhubungan dengan siapa yang membayar iuran dan bagaimana cukup pembayaran terdistribusi antara pengguna atau pelanggan (Mukherjee dan Wijk, 2000).

- Keuntungan

Kemauan pelanggan untuk membayar penggunaan sarana air minum dipengaruhi oleh keuntungan yang dirasakan, pendapatan, karakteristik, sumber air yang ada dan beberapa faktor lainnya (Briscoe dan Bredero, 1988). Dalam PMBOK edisi ke empat dinyatakan tujuan sebuah proyek yang dilakukan sementara itu bukan hanya sebatas keluaran tetapi untuk mendapatkan keuntungan yang berkesinambungan baik secara sosial, ekonomi dan dampak lingkungan. 


\section{E. Kepuasan masyarakat terhadap program PAMSIMAS}

Kepuasan terhadap pemenuhan kebutuhan sangat berhubung erat antara sistem pengelolaan sarana dan kontribusi yang dilakukan untuk pengelolaan tersebut. Pengguna air hanya akan mempertahankan layanan yang memenuhi harapan mereka, dan ini masuk dalam keberlanjutan sisi social (Mukherjeedan Wijk, 2000). Ini berarti layanan dapat mereka akses dengan mudah, yang sesuai dengan mereka sosial budaya yang ada, dan jasa yang masyarakat anggap senilai dengan biaya yang mereka keluarkan. Terdapat aspek kesetaraan yaitu melihat bagaimana kecukupan beban dan manfaat layanan dibagi di sosial ekonomi yang berbeda, gender dan kelompok tingkatan. Maka dari pernyataan diatas dapat diketahui indikator kepuasan masyarakat terhadap program PAMSIMAS yaitu :

1. Perasaan puas (dalam arti puas akan terhadap layanan kecukupan kebutuhan air minum) yaitu ungkapan perasaan puas atau tidak dari pengguna air atau penerima manfaat saat menerima pelayanan yang baik dari pengelola program.

2. Semakin meningkatnya jumlah penerima manfaat tiap tahunnya.

3. Terpenuhinya harapan pelanggan atau penerima manfaat air minum setelah menerima bantuan air minum dari program PAMSIMAS yaitu layak atau tidaknya kualitas air minum.

\section{F. Keberfungsian Sarana Air Minum (SAM)}

Keberfungsian dapat didefiniskan sebagai kemampuan dalam melaksanakan tugas-tugas. Untuk keberfungsian sarana air minum dibuktikan dengan berita acara uji fungsi secara teknis. Indikator keberfungsian sarana air minum dapat diketahui sebagai berikut :

1. Sumber Air

Sudah layak atau belum dalam hal Kualitas, Kuantitas dan akses jaringan pipa distribusi ke masyarakat.

2. Pengoperasian sarana

Sarana dalam akses air minum memiliki 2 (dua) jenis sistem yaitu sistem perpipaan dan sistem non-perpipaan. Sistem perpipaan adalah sistem penyaluran air minum yang menggunakan pipa atau saluran tertutup mulai dari pipa transmisi dan distribusi air hingga ke pelanggan atau penerima manfaat. Sebagai contoh sistem transmisi dan distribusi air minum dari sumber air (mata air maupun sumur bor) kepada kelompok pelanggan baik dalam bentuk hidran umum, kran umum maupun sambungan rumah (SR).

Sistem non-perpipaan adalah sistem yang tidak menggunakan perpipaan dalam menyalurkan air minum kepada penerima manfaat atau pelanggan. Sistem ini dapat berupa sumur dangkal, sumur pompa tangan, bak penampung air hujan, terminal air atau bangunan perlindungan mata air setempat.

\section{Pemeliharaan sarana}

Pemeliharanaan sarana dalam akses air minum juga dibagi dua sistem yaitu sistem perpipaan dan sistem nonperpipaan yang dilakukan pemilharaan secara harian, mingguan, bulanan dan tahunan.

\section{METODE PENELITIAN}

Lokasi yang dipilih untuk penelitian Evaluasi Pengembangan Sarana Air Minum (SAM) pada Program PAMSIMAS studi kasus di Kecamatan Kalinyamatan.

Waktu penelitian direncanakan berlangsung mulai dari bulan November sampai bulan Desember.

Adapun obyek penelitian dalam tulisan ini adalah : (1) Lokasi di Kecamatan Kalinyamatan (2) Keberhasilan program PAMISMAS (3) Ketepatan waktu program PAMSIMAS (4) Kontribusi dari masyarakat (5) Tujuan akhir program PAMSIMAS.

Data yang digunakan meliputi data primer melalui kuesioner juga data sekunder yang kita dapatkan dari instansi terkait.

Dalam penelitian ini populasinya adalah penerima manfaat pada program PAMSIMAS di desa Damarjati, Banyuputih dan Pendosawalan di Kecamatan Kalinyamatan Kabupaten Jepara.

Pengolahan Data

Data yang didapat dari hasil kuesioner kita olah dengan menggunakan excel dan SPSS, sehingga didapatkan suatu persamaan linear dengan variabel yang kita tentukan. 


\section{HASIL DAN PEMBAHASAN}

Gambaran umum responden digunakan untuk mengetahui identitas responden secara umum yang meliputi jenis kelamin, umur, dari desa mana, desa PAMSIMAS tahun keberapa, status keberfungsian PAMSIMAS, dan status pendidikan responden.

Dalam parameter responden ini dibagi menjadi 2 parameter sebagai berikut :

A. Parameter Penilaian Skor Kuesioner

B. Parameter Kriteria Nilai Indeks Prosentase

Tetapi sebelum diambil analisis data secara keseluruhan, terlebih dahulu dilihat dari kelengkapan berdasarkan item variabel yang mempengaruhi indikator evaluasi, indikator kendala dan indikator strategi pada pengembangan sarana air minum dari program PAMSIMAS di Kecamatan Kalinyamatan.

\subsection{Analisis Mean Rank}

Dari hasil pengisian kuesioner oleh responden, maka dari pengisian tersebut dihasilkan suatu data statistic yang mempengaruhi indikator dalam variabelvariabel kuesioner.:

1. Mean rank menunjukkan nilai rata-rata dari masing-masing variabel dan indikator. Satiap variabel berisi tentang indikator evaluasi, indikator kendala dan indikator strategi yang berpengaruh terhadap variabel pelaksanaan program PAMSIMAS, variabel fungsi PAMSIMAS dan variabel rencana kedepan program PAMSIMAS.

2. Total Skor dari pengolahan indikator terhadap variabel.

3. Nilai Indeks prosentase yang nantinya digunakan sebagai acuan dalam penentuan ranking.
4. Penentuan nilai indeks prosentase diperoleh dari kriteria skor terbesar dalam jawaban kuesioner yaitu Setuju dengan skor 5 dikalikan (N) jumlah total responden yaitu 30 orang dibagi dengan total skor setiap indikator pertanyaan dan dikali indeks prosentase yaitu $100 \%$

5. Setelah ditemukan nilai indeks dari prosentase terbesar hingga prosentase terkecil, kemudian dibuatlah perankingan kuesioner dengan nilai indeks prosentase terbesar hingga ke prosentase terkecil.

\subsection{Analisis Regresi Linier Berganda}

Dimana analisis ini untuk mengetahui hubungan antara variabel independent (X1) yaitu Pelaksanaan Program PAMSIMAS dan (X2) Fungsi Program PAMSIMAS dengan variabel dependen yaitu (Y) Rencana Kedepan Program PAMSIMAS. Persamaan regresi linier berganda sebagai berikut :

$$
\begin{aligned}
& \mathrm{Y}^{\prime}=\mathrm{a}+\mathrm{b} 1 \mathrm{X} 1+\mathrm{b} 2 \mathrm{X} 2+\ldots . .+\mathrm{bnXn} \\
& \text { Dimana, } \\
& \mathrm{Y}^{\prime} \quad \text { : Variabel dependen (nilai } \\
& \text { yang diprekdisikan) } \\
& \mathrm{X} 1 \text { dan X2 : Variabel independen } \\
& \text { a : Konstanta (nilai } Y \text { ' } \\
& \text { apabila } \mathrm{X} 1, \mathrm{X} 2 \ldots . \mathrm{Xn}= \\
& 0)
\end{aligned}
$$

\begin{tabular}{|c|c|c|c|c|c|c|c|c|}
\hline \multicolumn{9}{|c|}{ Coefficients ${ }^{\mathrm{a}}$} \\
\hline & & \multicolumn{2}{|c|}{$\begin{array}{l}\text { Unstandardized } \\
\text { Coefficients }\end{array}$} & \multirow{2}{*}{$\begin{array}{c}\text { Standardize } \\
\mathrm{d} \\
\text { Coefficients } \\
\text { Beta } \\
\end{array}$} & \multirow[b]{2}{*}{$\mathrm{t}$} & \multirow[b]{2}{*}{ Sig. } & \multicolumn{2}{|c|}{$\begin{array}{l}\text { Collinearity } \\
\text { Statistics }\end{array}$} \\
\hline \multicolumn{2}{|c|}{ Model } & B & $\begin{array}{l}\text { Std. } \\
\text { Error }\end{array}$ & & & & Tolerance & VIF \\
\hline \multirow[t]{3}{*}{1} & (Constant & $\begin{array}{r}25.69 \\
9 \\
\end{array}$ & 22.080 & & 1.164 & .255 & & \\
\hline & $\mathrm{X} 1$ & .182 & .477 & .073 & .383 & .705 & .988 & 1.013 \\
\hline & $\mathrm{X} 2$ & .165 & .255 & .124 & .646 & .524 & .988 & 1.013 \\
\hline
\end{tabular}

Tabulasi data kuesioner yang didapat pada kolom coefficients dan Casewise diagnostics yang didapat dengan bantuan program SPSS adalah sebagai berikut :

a. Dependent Variable: X3

Sumber : Hasil Analisis Data SPSS, 2021

Persamaan regresinya sebagai didapatkan yaitu sebagai berikut :

$$
\mathrm{Y}^{\prime}=\mathrm{a}+\mathrm{b}_{1} \mathrm{X}_{1}+\mathrm{b}_{2} \mathrm{X}_{2}
$$




$$
Y^{\prime}=25,699+0,182 X_{1}+0,165 X_{2}
$$
Dimana,

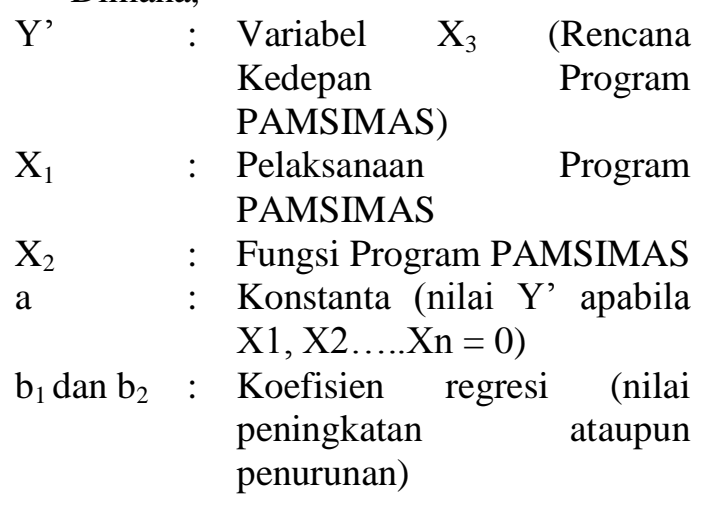

Dari hasil analisis regresi linier berganda diperoleh persamaan regresi diatas dapat dijelaskan sebagai berikut :

1. Konstanta sebesar (a) 25,699 , artinya nilai positif konstanta menunjukan pengaruh positif variabel independen (Pelaksanaan program dan Fungsi Program). Bila variabel independen naik atau berpengaruh dalam satu satuan, maka variabel rencana kedepan akan terpenuhi.

2. Koefisien regresi untuk variabel $X_{1}$ sebesar 0,182 dan $\mathrm{X}_{2}$ sebesar 0,165

3. Koefisien regresi vairiabel pelaksanaan program PAMSIMAS $\left(\mathrm{X}_{1}\right)$ terhadap variabel rencana kedepan program PAMSIMAS (Y') artinya jika pelaksanaan program PAMSIMAS $\left(\mathrm{X}_{1}\right)$ akan mengalami peningkatan sebesar 0,182 atau $18,2 \%$. Koefisien bernilai positif artinya hubungan antara pelaksanaan program PAMSIMAS $\left(\mathrm{X}_{1}\right)$ untuk rencana kedepan program PAMSIMAS (Y') memiliki hubungan positif akan mengakibatkan pengaruh baik pada rencana kedepan program PAMSIMAS (Y').

4. Kofisien regresi variabel fungsi program PASMIMAS $\left(\mathrm{X}_{2}\right)$ terhadap variabel rencana kedepan program PAMSIMAS (Y') memiliki nilai positif sebesar 0,165 . Artinya fungsi program PAMSIMAS $\left(\mathrm{X}_{2}\right)$ mengalami suatu kenaikan satu satuan, maka rencana kedepan program PAMSIMAS (Y') akan mengalami peningkatan sebesar 0,165 atau $16,5 \%$ kofisien bernilai positif artinya kenaikan fungsi program PAMSIMAS $\left(\mathrm{X}_{2}\right)$ akan berpengaruh baik pada rencana kedepan program PAMSIMAS (Y').

Menurut Sugiyono (2007) pedoman untuk memberikan interpretasi koefisien korelasi sebagai berikut:
$0,00-0,199=$ sangat rendah
$0,20-0,399=$ rendah
$0,40-0,599=$ sedang
$0,60-0,799=$ kuat
$0,80-1,000=$ sangat kuat

Tabel 7. Hasil analisis korelasi ganda

\begin{tabular}{|c|c|c|c|c|}
\hline \multicolumn{4}{|c|}{ Model Summary $^{\mathbf{b}}$} & Adjusted R \\
Model & $\mathrm{R}$ & $\mathrm{R}$ Square & $\begin{array}{c}\text { Std. Error of } \\
\text { Square }\end{array}$ & the Estimate \\
\hline 1 & $\mathbf{. 1 5 1}^{\mathrm{a}}$ & .023 & -.050 & 2.429 \\
\hline \multicolumn{4}{|c}{ a. Predictors: (Constant), X2, X1 } \\
\hline
\end{tabular}

Sumber : Hasil Analisis Data SPSS, 2021

Berdasarkan tabel diatas diperoleh angka $\mathrm{R}$ sebesar 0,151 . Hal in menunjukan bahwa terjadi hubungan sangat rendah antara pelaksanaan program PAMSIMAS dan fungsi program PAMSIMAS terhadap rencana kedepan program PAMSIMAS. Angka $\mathrm{R}$ ini digunakan untuk mengetahui hubungan antara dua atau lebih variabel independen $\left(\mathrm{X}_{1}\right.$, $\mathrm{X}_{2, \ldots} \mathrm{X}_{\mathrm{n}}$ ) terhadap variabel dependen ( $\mathrm{Y}^{\prime}$ ) secara serentak.

Berdasarkan tabel diatas juga diperoleh $\mathrm{R}$ square $\left(\mathrm{R}^{2}\right)$ atau determinasi dalam regresi linier berganda. Analisis ini digunakan untuk mengetahui prosentase sumbangan pengaruh variabel independen $\left(\mathrm{X}_{1}\right.$ dan $\left.\mathrm{X}_{2}\right)$ secara serentak terhadap variabel dependen (Y'). Jika $\mathrm{R}^{2}$ ( $\mathrm{R}$ square) sama dengan 0 , maka tidak ada sedikitpun prosentase sumbangan pengaruh yang diberikan variabel independen terhadap

variabel dependen, atau variasi variabel independen yang digunakan dalam model tidak menjelaskan sedikitpun variasei variabel dependen. Sebaliknya jika $\mathrm{R}^{2}$ (R square) sama dengan 1, maka prosentase sumbangan 
pengaruh yang diberikan variabel independen terhadap variabel dependen adalah sempurna atau variasi variabel independen yang digunakan dalam model menjelaskan $100 \%$ variasi variabel dependen

Tabel 8. R Squaer $\left(R^{2}\right)$

\begin{tabular}{|c|c|c|c|c|}
\hline \multicolumn{5}{|c|}{ Model Summary } \\
\hline Model & $\mathrm{R}$ & R Square & Adjusted R Square & Std. Error of the Estimate \\
\hline 1 & $.151^{\mathrm{a}}$ & .023 & -.050 & 2.429 \\
\hline
\end{tabular}

Sumber : Hasil Analisis Data SPSS, 2021

\section{PENUTUP}

Berdasarkan analsisi data diatas, maka dapat ditarik kesimpulan dalam penelitian ini adalah sebagai berikut :

Evaluasi untuk variabel pelaksanaan program PAMSIMAS dan variabel fungsi program PAMSIMAS terhadap variabel rencana kedepan pengembangan Sarana Air Minum (SAM) sebesar 0,182 atau 18,2\% dan 0,165 atau $16,5 \%$. Dan memiliki nilai positif yang memiliki pengaruh baik pada variabel pelaksanaan dan variabel fungsi dengan variabel rencana kedepan.

Variabel pelaksanaan program dengan variabel fungsi program PAMSIMAS memiliki prosentase sebesar 23\% untuk pengembangan Sarana Air Minum (SAM), sisanya $67 \%$ dipengaruhi atau dijelaskan oleh variabel lain yang tidak dimasukan dalam model penelitian ini.

Dari hasil uji regresi linier berganda diperoleh persamaan yaitu $Y=\mathbf{2 5 , 6 9 9}+\mathbf{0 , 1 8 2} \times \mathbf{X 1}+$ $0,165 \times$ X2.

Strategi untuk mengembangkan PAMSIMAS di Kecamatan Kalinyamatan dalam variabel rencana kedepan adalah perlunya meningkatkan fungsi program PAMSIMAS karena masih memiliki nilai positif hanya sebesar 0,165 atau $16,5 \%$. Jika dibandingkan dengan variabel pelaksanaan program PAMSIMAS memiliki nilai positif sebesar 0,182 atau $18,2 \%$

\section{DAFTAR PUSTAKA}

Amalia, K. R. (2019). Evaluasi Pengelolaan Program Penyediaan Air Minum dan Sanitasi Berbasis Masyarakat di Jorong Gurun Kecamatan Harau Kabupaten
Lima Puluh Kota. Jurnal Talenta Sipil. https : // doi.org / 10.33087/ talentasipil. v2i1. 12

Balitbang PU. (2013). Pedoman Pembangunan Sarana dan Prasarana Air Minum. In Modul sosialisasi dan diseminasi SPM: Vol. I (Issue 5).

Nazar, T. M., Azmeri, A., \& Fatimah, E. (2018). Evaluasi Keberhasilan Pengelolaan Program Penyediaan Air Minum dan Sanitasi Berbasis Masyarakat di Kabupaten Aceh Besar. Jurnal Teknik Sipil. https://doi.org/10.24815/jts.v1i4.10063

Pemerintah Direktorat Jendral Bina, \& Indonesia, K. D. N. R. (2008). Petunjuk Pelaksanaan. 4107.

Pratama, A. B., \& Isnanik, A. T. (2018). Evaluasi Berjalan Program Penyediaan Air Minum dan Sanitasi Berbasis Masyarakat. Jurnal Ilmu Administrasi: Media Pengembangan Ilmu Dan Praktek Administrasi.

https://doi.org/10.31113/jia.v15i2.148

PROGRAM PENYEDIAAN SARANA AIR MINUM DAN SANITASI BERBASIS MASYARAKAT (PAMSIMAS) Fieldbook Proses Identifikasi Masalah dan Analisis Situasi. (2010).

Sugiyono (2005). Pengertian Populasi dan Teknik Sampling.

Welli Sanjaya, Yuwanto, Puji Astuti, (2013). Evaluasi Pelaksanaan Program Pamsimas (Penyediaan Air Minum Dan Sanitasi Berbasis Masyarakat) Tahun 2009-2010 Di Kabupaten Grobogan. Jurnal Ilmu Pemerintahan. 